\title{
The nature and detection of unauthorized waste dump sites using remote sensing
}

\author{
Sergij Vambol ${ }^{1}$,Viola Vambol ${ }^{1}$, Muniyan Sundararajan², Iqbal Ansari ${ }^{2 *}$ \\ ${ }^{1}$ Berdyansk State Pedagogical University, Schmidt str., 4, Berdyansk, Zaporizhia region, Ukraine, 71100 \\ ${ }^{2}$ Department of Natural Resource and Environmental Management Group, \\ CSIR-Central Institute of Mining and Fuel Research \\ Barwa Road, Dhanbad-826015, Jharkhand, India, "e-mail: iqbal.cimfr@gmail.com
}

Received: 21 February 2019 / Accepted: 10 May 2019

\begin{abstract}
Now a day's waste disposal has become a massive tricky for environmentalist, as it is responsible for a various issue such as sanitary hygienic, ecological security, illegal dumps, lack of paved or asphalt access roads to the landfill, inadequate treatment facilities and low efficiency of public services of waste management. In the present study, we have discussed the detection of unauthorized dumps of municipal solid waste being potential raw materials for biofuel obtaining. The aim of the study is to investigate the possibility of using wide access data of remote sensing of Earth and geographic information technologies for operative detection of unauthorized waste dumps for the further extraction of waste from the environment to turn them into biofuel. The topicality of the study is substantiated with the complexity of detection of unauthorized waste dumps due to their multiplicity adjoined with unknown geographic and temporary dislocation. The universal classification of the image does not allow detecting unauthorized waste dumps and determining whether these wastes may be the source of potential raw materials for biofuel obtaining. The research results show that the developed specialized model based on the exclusion of the low hazard dumpsites allows distinguishing dump areas enriched with carbon-containing materials.
\end{abstract}

Key words: carbon-containing organic material, searching renewable energy source.

\section{Introduction}

The unauthorized dump of urban wastes is the open site disposal of waste at private or public places other than the designated waste processing sites (Corbyn, 2008; Tompson \& Chainey, 2011; Chanakya et al., 2015). Angelino et al. (2018) reported detection of illegal dumps from optical satellite images in a large territory falling in the provinces of Naples and Caserta, Southern Italy. The detection was performed via expert photo-interpretation in order to achieve a high level of accuracy and reliable maps. This technique will be effective in both finding new illegal spills (with associated macro classification) and to follow the evolution (in terms of extension and persistence) of landfills already found in the past. A study (Katharine \& Chang, 2015) reports the assessment of existing remote sensing (RS) methods for mapping of illegal domestic waste sites in Queensland, Australia. It analyzes the existing RS methods and sensors used to monitor and map of illegal waste disposal sites. Silvestri \& Omri (2008) has validated a method which is based on remotely sensed information and a geographic information system (GIS) to identify unknown landfills over large areas using IKONOS satellite data. Their results reveal that integration of automatic recognition methods based on RS data with the intervention of human operators and with spatially distributed geographic information is a necessity for the selection of the most likely contaminated sites. Similarly, Chinatsu (2009) investi- 
gated the usefulness of ALOS (Advanced Land Observing Satellite) and Quickbird earth observation satellites on land areas using data. Their results indicate that a landfill site can be identified and temporal changes in the disposal site are clearly evident on PRISM imagery. Pan-sharpened PRISM and AVNIR-2 images are useful for image interpretation. Spatial resolution improvements, shorter observation intervals, and data-cost reductions could make satellite imagery practically useful in waste monitoring.

Today, many scientists are busy searching for renewable energy sources (Malovanyy et al., 2016; Vambol S. et al., 2018a). In the same time the problem of unauthorized waste dumps is sharp (Gorova et al., 2015). One of the reasons for environmentally dangerous wastes to occur is scientific and technical progress in the development of new materials. Wastes accumulated at unauthorized dumps consist of debris, rock masses and of municipal solid waste (MSW). However, the basis of different types of wastes includes carbon-containing organic materials, which may be used as a raw material for biofuel production. Revealing of unauthorized waste dumps is complex due to their multiplicity, small areas, and unknown spatial and temporary distribution. As a rule, the detection of waste dumps occurs accidentally. And the rates of decomposition of different substances in the whole mass of wastes are not the same. That is why the influence of individual fractions of wastes on the formation of leachate is different. That means that the term since the start of dump formation until the beginning of leachate penetration into ground waters is unknown. Therefore, at the moment of dump detection, negative consequences of leachate influence on the environment may already be significant.

MSW contains components, which may become the nutrients for wide enough specters of microorganisms species. Some of them are dangerous for human health and environmental condition. The climate in Ukraine promotes intensive reproduction of bacteria. It is a well-known fact that all of the living organisms consist mostly of hydrocarbons the same as most of the waste dumps. Thus, the monitoring of microbiological pollution of urbanic systems should take one of the most important places in the structure of the appropriate environmental safety management system.

Written above is more relevant in case of application of activities for increasing of indicators of the environmental safety level of legal and unauthorized places of solid wastes accumulation having a technogenic origin. For example, in scientific papers (Vambol S. et al., 2017a; Suchikova et al., 2017; Vambol S. et al., 2017b) investigated the hazard of materials with nano-inclusions and methodological and technogenic and environmental aspects of the technological process of utilization of polymers with nanoinclusions using thermal decomposition.
Thus, the task of unauthorized waste dumps detection for the purpose of carbon-containing materials extraction for biofuel production is topical both in the spheres of waste management and rational environmental management.

All components of wastes have different densities, overall sizes, chemical composition, and reflecting ability. These differences cause certain complexity in the detection of the waste dump on space images. A technique of waste dump contour recognition by means of brightness and texture method is described in articles (Oreshkina, 2005; Novokhatska, 2015).

Data of remote sensing of Earth (RSE) from the space satellite is the source of information allowing obtaining an actual operative image of places of location of unauthorized waste dumps with lower time expenses. Articles (Domanska \& Bondar, 2013; Kohan \& Moskalenko, 2009) are dedicated to analysis and searching of possibilities of application of multispectral space images for identification of unauthorized dumps by means of determination of their brightness characteristics. Articles of foreign scientists (Wood \& Lee, 1995; Cui et al., 2008) are dedicated to decoding of space images. RSE methods in combination with the application of geographic information systems (GIS) and mathematical simulation methods provide opportunities for complex studying of sources of formation of environmental hazards adjoined with the decision-making about the ways to handle them. Using enlisted approach is proposed in works of O.M. Trofymchuk, S.S. Kokhan, A.A. Moskalenko, M.A. Aristov, and others (Trofimchuk \& Novokhatka, 2014; Aristov, 2009). Technique of dump contour recognition using both brightness and texture methods is represented in works (Oreshkina, 2005; Vambol V. et al., 2015). Artificial brightness attributes constructing is also possible.

The aim of the study is to investigate the possibility of application of wide access data of RSE and GIS-technologies for operative detection of places of unauthorized accumulation of waste, analysis of their development for the further extraction of waste from the environment and turning them into biofuel.

\section{Methodology}

Development of a model for detecting of unauthorized waste dump is accomplished using satellite image. For successful realization of tasks of the study we have used the space images with ultrahigh spatial resolution of (0.5-15) $\mathrm{m}$ in spectral range of (0.4-1.1) microns wavelengths, namely QuickBird, WorldView, GeoEye, Pleiades, Ikonos, etc. Such images may be obtained from archive databases of cartographic servers through the Internet. The most available source of such images is online free service 
Google Earth. In current study we have used specifically these images. The digital equivalent of brightness for each image points is the mean value of brightness in point surrounding or median of sequence of brightness of elements in surrounding of the point. As brightness attributes of objects which includes some multiplicity elements of image using the histogram of brightness. The corresponding brightness attributes for certain complex object including multiple image points are the mean value of points brightness combined with the dispersion, asymmetry coefficient, and excess of the sequence' brightness values:

$$
\begin{aligned}
& \mathrm{m}=\frac{1}{n-1} \sum_{i, j} I_{i, j}, \\
& D=\frac{\sum_{i, j}\left(I_{i, j}-m\right)^{2}}{n-1}, \\
& S=\frac{\sum_{i, j}\left(I_{i, j}-m\right)^{3}}{(n-1) D^{3 / 2},} \\
& K r=\frac{\sum_{i, j}\left(I_{i, j}-m\right)^{4}}{(n-1) D^{4}},
\end{aligned}
$$

where $\mathrm{m}$ - the mean value of pixels brightness in sensing window; I - the value of pixel brightness; i, j - the coordinates of pixels in sensing window; $\mathrm{n}-$ the quantity of pixels in sensing window; $\mathrm{D}$ - the dispersion of brightness values; $\mathrm{S}$ - the asymmetry coefficient of brightness values; $\mathrm{Kr}-$ the excess of brightness values.

For computer processing of image structure attributes it is necessary to use special procedures of their formalization. At object brightness surface distribution attribute formalization we have used the procedure of image brightness field decomposition into specter of spatial frequencies. For the linear processing with square window sliding over the image the brightness of transformed image is determined as:

$$
f(i, j)=\sum_{i=i_{0}-w}^{i_{0}+w} \sum_{j=j_{0}-w}^{j 0+w}\left(\begin{array}{l}
F(i, j) H \times \\
\times\left(i-i_{0}+w+1,\right. \\
\left.j-j_{0}+w+1\right)
\end{array}\right),
$$

where $\mathrm{H}$ - the predetermined mask of operator of linear transforming built in the form of matrix of $(2 \mathrm{w}+1) \times$ $\times(2 \mathrm{w}+1)$ size; $\mathrm{f}-$ field of parameters of transformed image.

The transformation is the operation of discrete convolution of image with mask H. For decomposition of field of image $F(j, k)$ into specter of spatial frequencies we have used different procedures of unitary transformations: Fourier, Hadamard, Haar, and oblique transformation. In general case for square form sliding window of $\mathrm{N} \times \mathrm{N}$ size the spectral coefficients $f(u, v)$ are described with the following formula:

$$
f(u, v)=\frac{1}{N} \sum_{j=0}^{N} \sum_{k=0}^{N} F(j, k) A(j, k, u, v),
$$

where $A(j, k, u, v)$ - the core of direct transformation.

The set of spectral coefficients is the attribute characterizing the variation of image surface brightness in the fullest way. For this attribute formalization we have also used simplified approaches. The essence of one of them is in application of the brightness gradient value. For its implementation we have executed the procedure of spatial differentiation of analyzed image fragment found with derivations $\mathrm{dF} / \mathrm{dx}$ and $\mathrm{dF} / \mathrm{dy}$ by means of convolution of image with gradient masks $\mathrm{H}_{\mathrm{x}}$ and $\mathrm{H}_{\mathrm{y}}$. The formalized attributes directly use values of $\mathrm{dF} / \mathrm{dx}$ and $\mathrm{dF} / \mathrm{dy}$ and values of gradient module and tangent of angle of declination to axis OX.

The most complex is the procedure of formalization of the image texture, which represents the object itself with its shape, sizes, and relative location of elements. Texture is characterized with the spatial repeatability of local structure of brightness field. Thus, the texture may be qualitatively described with the value of repeatability period. They use different approaches to describe the texture quantitatively (Kalinin, 2013). The one of them is based on analysis of the specter of spatial frequencies. The big texture corresponds to specter, which energy is concentrated on low spatial frequencies, and the small texture corresponds to the high-frequency one.

To automate the process of analysis we have programmed all attributes into Erdas environment in Model Maker. The model of distinguishing criteria determination using sensing window with the space image is shown in Figure 1. The window matrix was selected on the basis of two factors superposition. The bigger the matrix is, the higher the reliability of attributes composition is. Instead the smaller the matrix is, the higher is accuracy of distinguishing of objects one from another. Thus we have chosen the size of sensing window equal to $5 \times 5$.

The direct separation of organic component of the waste dump from the inorganic is the task actualized with multiple mistakes of the first kind. It is explained with the fact that organics at the space images is similar on brightness and texture attributes with the surrounding planting (grass, forest, etc.). Taking into account the practical experience of scientific investigations in the field of space images recognition the task of indirect detection of organic waste dump areas arises. 
We propose to accomplish the indirect detection by means of exclusion of low-hazard waste dumpsites from the image. Such areas concern to accumulation of debris and rock masses. They may be easily identified at the background of surrounding planting on brightness and texture attributes due to high contrast level.

The range of brightness values of the pixels belonging to the waste dump may be determined by means of histograms calculation and generalized model development. For example, the landfills histograms shown at the Figure 2 allow choosing the following ranges of the investigated object attributes:

- the mean value of brightness $-(130-195) \mu \mathrm{m}$;

- the brightness dispersion - $(6-30) \mu \mathrm{m}$;

- the brightness asymmetry coefficient - $(0-4) \mu \mathrm{m}$;

- the brightness excess $-(0-14) \mu \mathrm{m}$.

To automate the process of analysis we have programmed all ranges into the model in Model Maker (Fig. 3). To distinguish the site of debris and rock masses dislocation we have to separate the histogram area into sub-ranges. The other way is to recreate the database of ranges of statistical moments of identified objects by means of their distinguishing at the image and building attributes ranges from the corresponding histograms. After identification of landfill sites with debris, we may define the rest of its territory as the one containing carbon compounds and organic elements. Using such operations we obtain the area of the waste dump with predominance of organic component. The scheme of the model of automated recognition of the landfill of the wastes with organic component is shown in Figure 4.

\section{Results and Discussion}

We have tested the proposed method on the example of Derhachi MSW landfill located in Kharkiv region, Ukraine. The filling of this landfill with waste is carried out by the card method, as this method allows carrying out waste disposal activities in stages. We have used space image of the landfill dated with October, 2017 for approbation. The space image had spatial reference for determination of the surface area. In this work, the scientific approach to the creation of a system for the prompt detection of a landfill in terms of the extraction of the carbon-containing component of waste was further developed, which makes it possible to increase the efficiency of environmental monitoring. Models with parameters of mean, dispersion, excess and asymmetry are presented in Figure 5-7 and histograms are shown in Figure 8, 9.

Once in accordance with the histograms all the required parameters have been determined to identify the zone of waste accumulation, we combine their common model and find the boundary of the waste dump (select the landfill from other landscape elements). Table 1 contains parameters of recognition of the waste dump. The borders of the recognized waste dump are shown on the map (see Fig. 10).

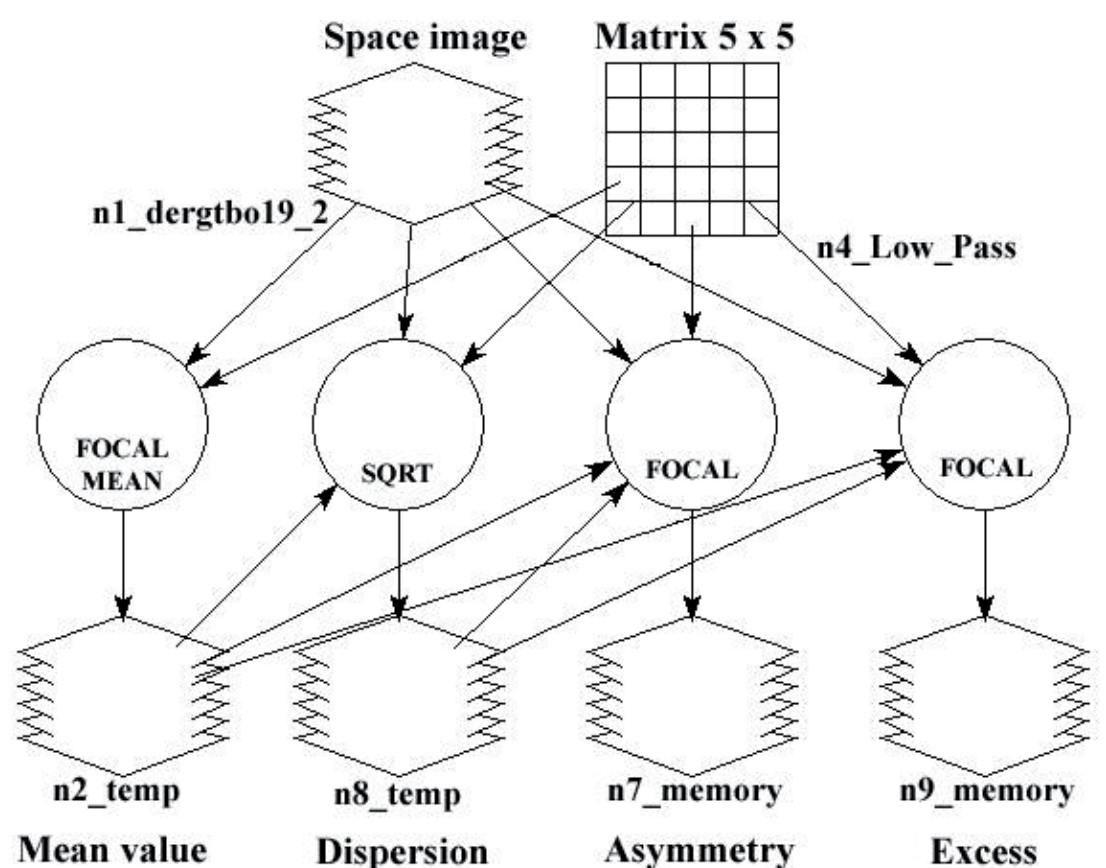

Figure 1. Model of distinguishing criteria determination 


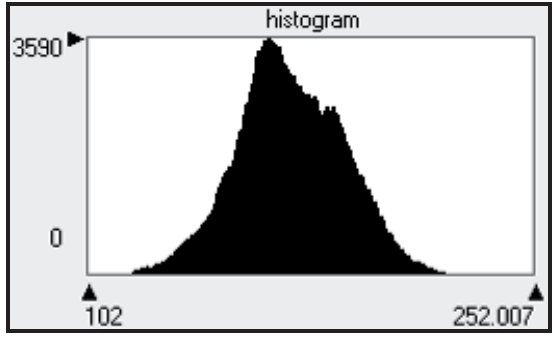

a

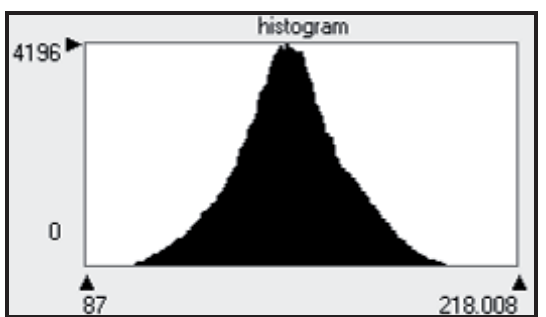

c

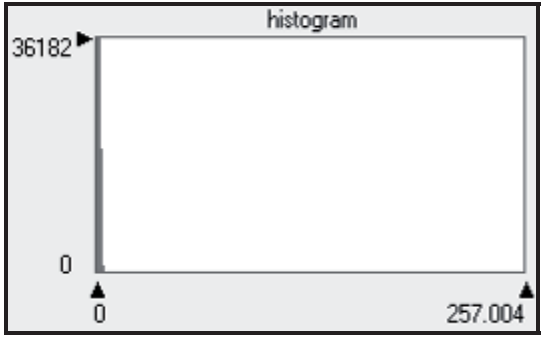

e

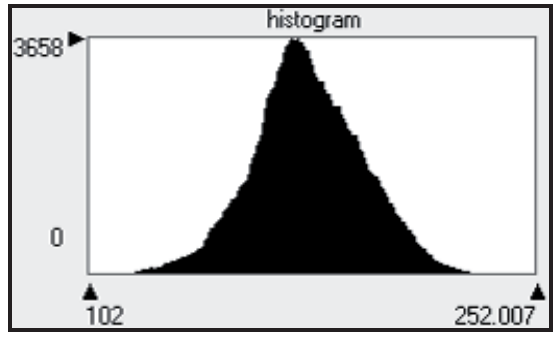

b

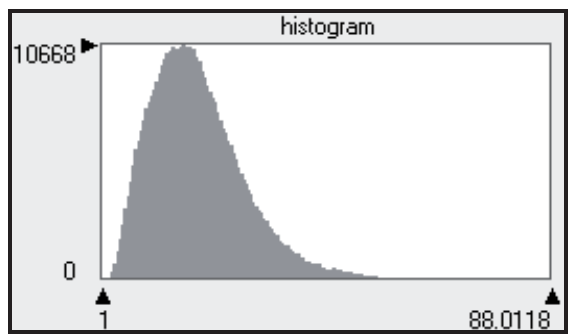

d

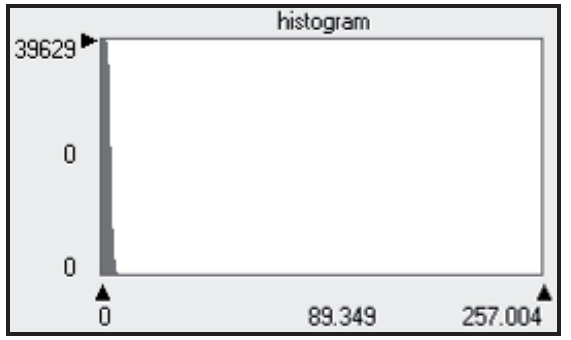

f

Figure 2. Histograms of landfills with debris and rock masses: $a$ - red channel of the mean value; $b$ - green channel of the mean value; $\mathrm{c}$ - blue channel of the mean value; $\mathrm{d}$ - blue channel of the dispersion value; $\mathrm{e}$ - red channel of the asymmetry value; $f-$ red channel of the excess value

The vectorization and determination of the area was carried out with an error that lies in the geographic system itself and the spatial reference of the image to this coordinate system. For this, a snapshot was uploaded to ArcMap (Fig. 10), a shapefile was created, a vectorization was performed (Fig. 11), and the area occupied by organic waste was calculated. In this case, the resulting area does not take into account elements of debris and rock masses.

Vectorization results and waste dump surface area calculation are shown in Figure 11 and Figure 12 correspondingly. The surface area of the dump in this case is equal to $162,131 \mathrm{~m}^{2}$.

Observations were made within one year. We have used five images obtained for different months. Wherein obtained results were compared with the actual dump characteristics. All obtained results were identical (Figs 13, 14).
The dynamics of changes in the carbon-containing wastes area shows not only a constant increase in the area occupied by waste and its decrease in some months of the year. This is explained by the fact that, firstly, the generation of waste during the year is uneven. Secondly, the following works are carried out at the landfill: waste distribution on the landfill territory, pouring on of waste by the ground and increasing their in density. Therefore the landfill itself (the place where the waste is dumped, which brought by the machines) may decrease or increase. Analysis of changes in the landfill area at the Dergachevsky landfill is necessary as a test version for further using of the methodology in order to be able to find unknown and unauthorized landfills.

Organic component of wastes detected by means of the model proposed should be sent for utilization allow- 


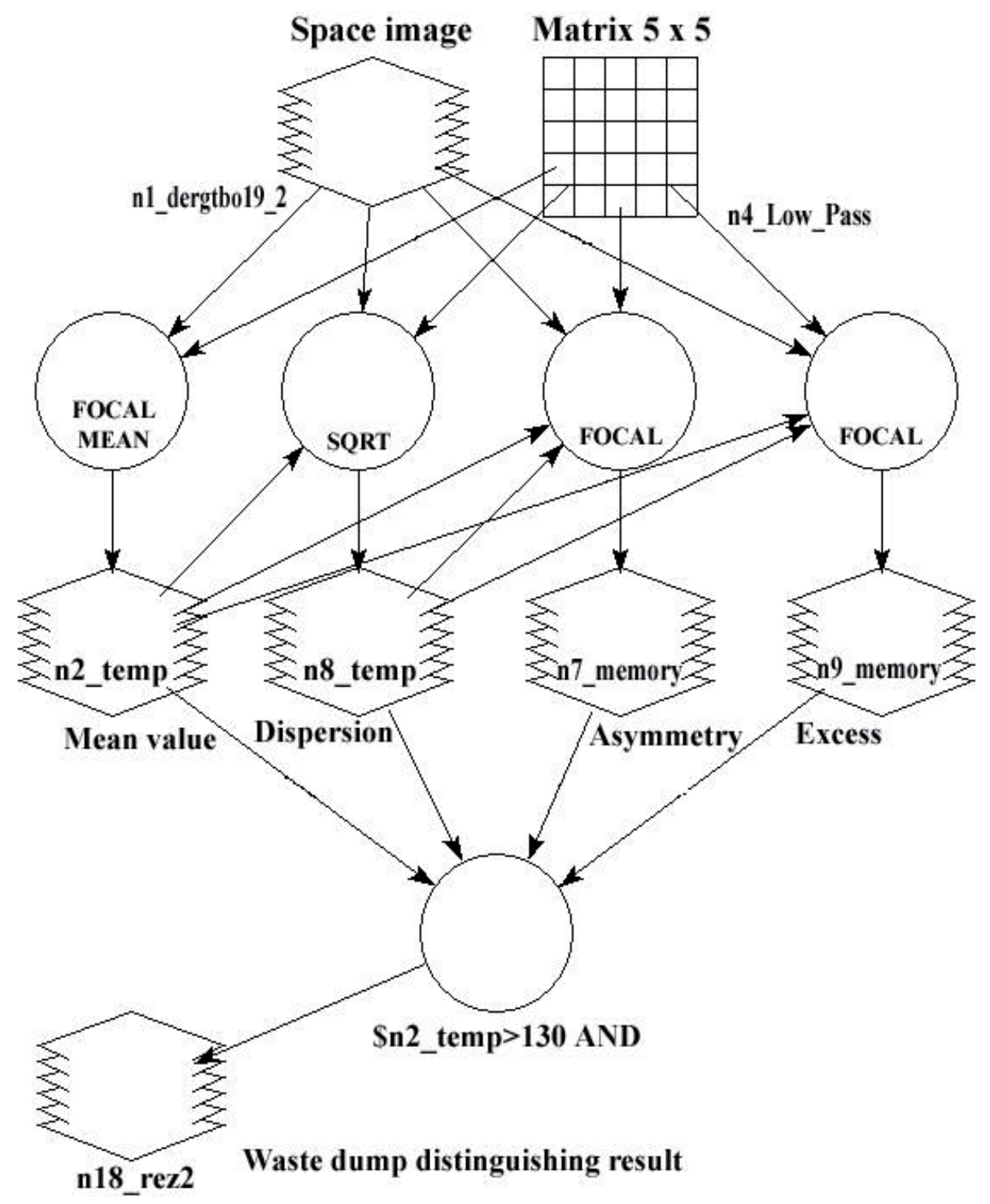

Figure 3. Scheme of the model of automated recognition of the waste accumulation area 


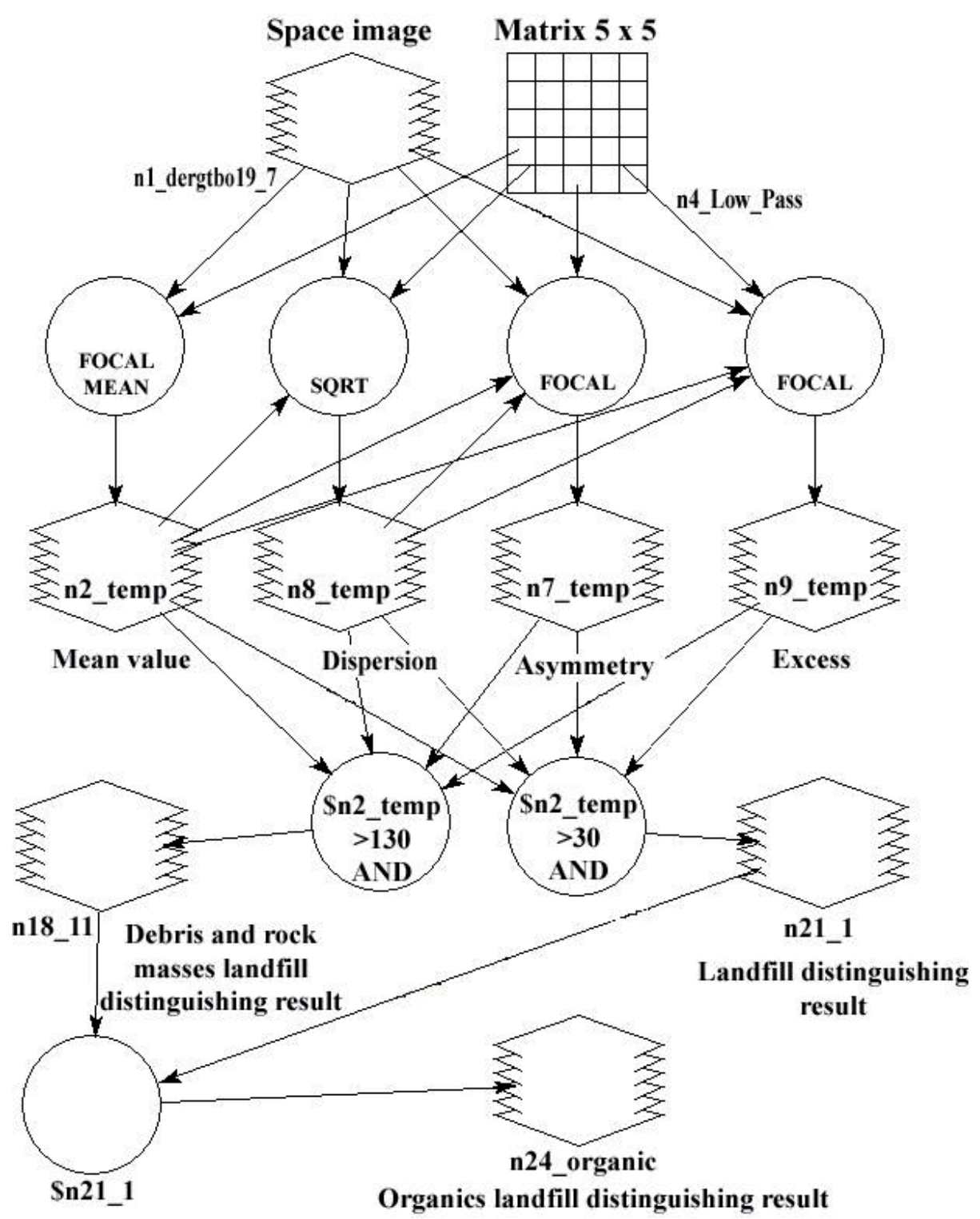

Figure 4. Scheme of the model of automated recognition of the landfill of the wastes with organic component 


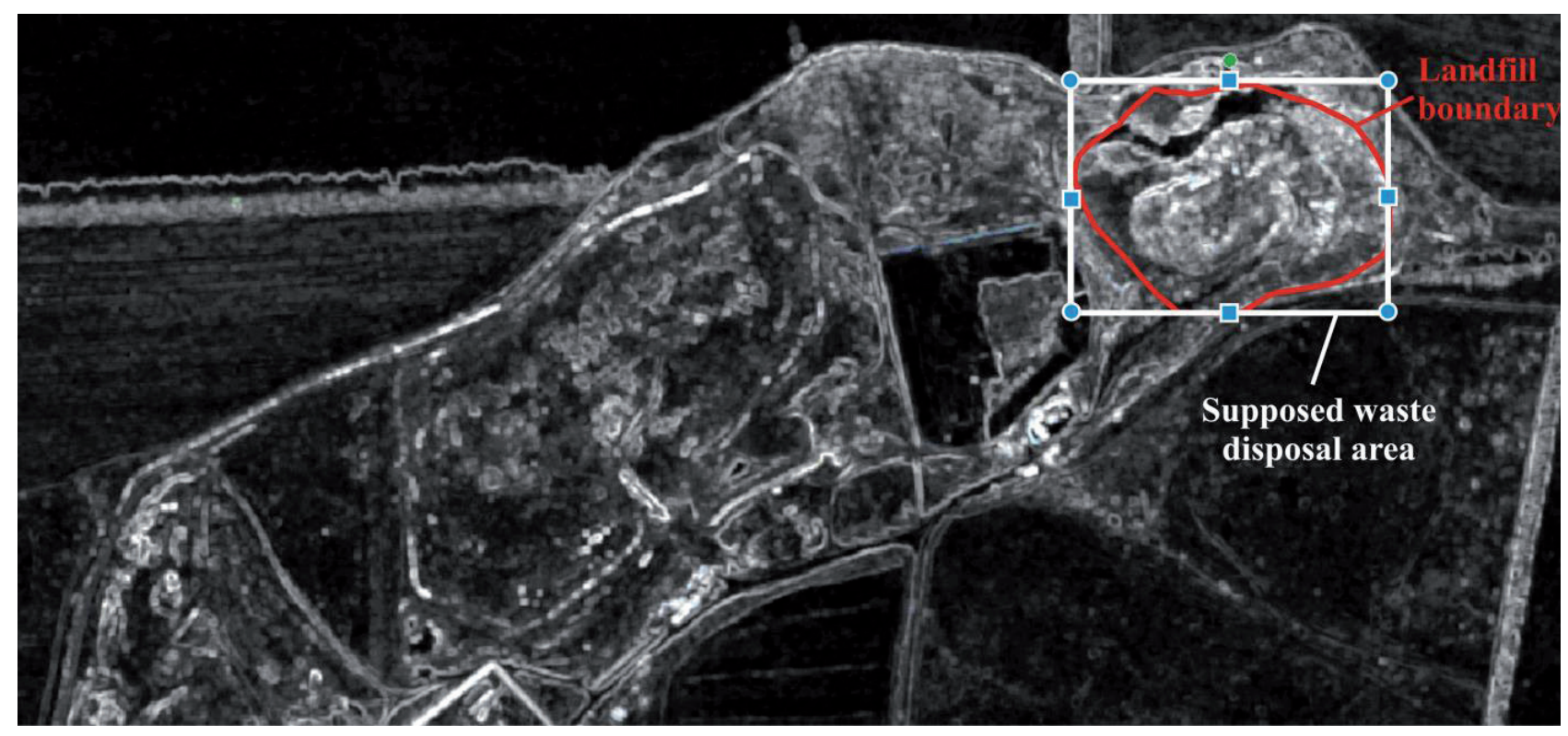

Figure 5. Dispersion built for Derhachi MSW landfill (October, 2017)

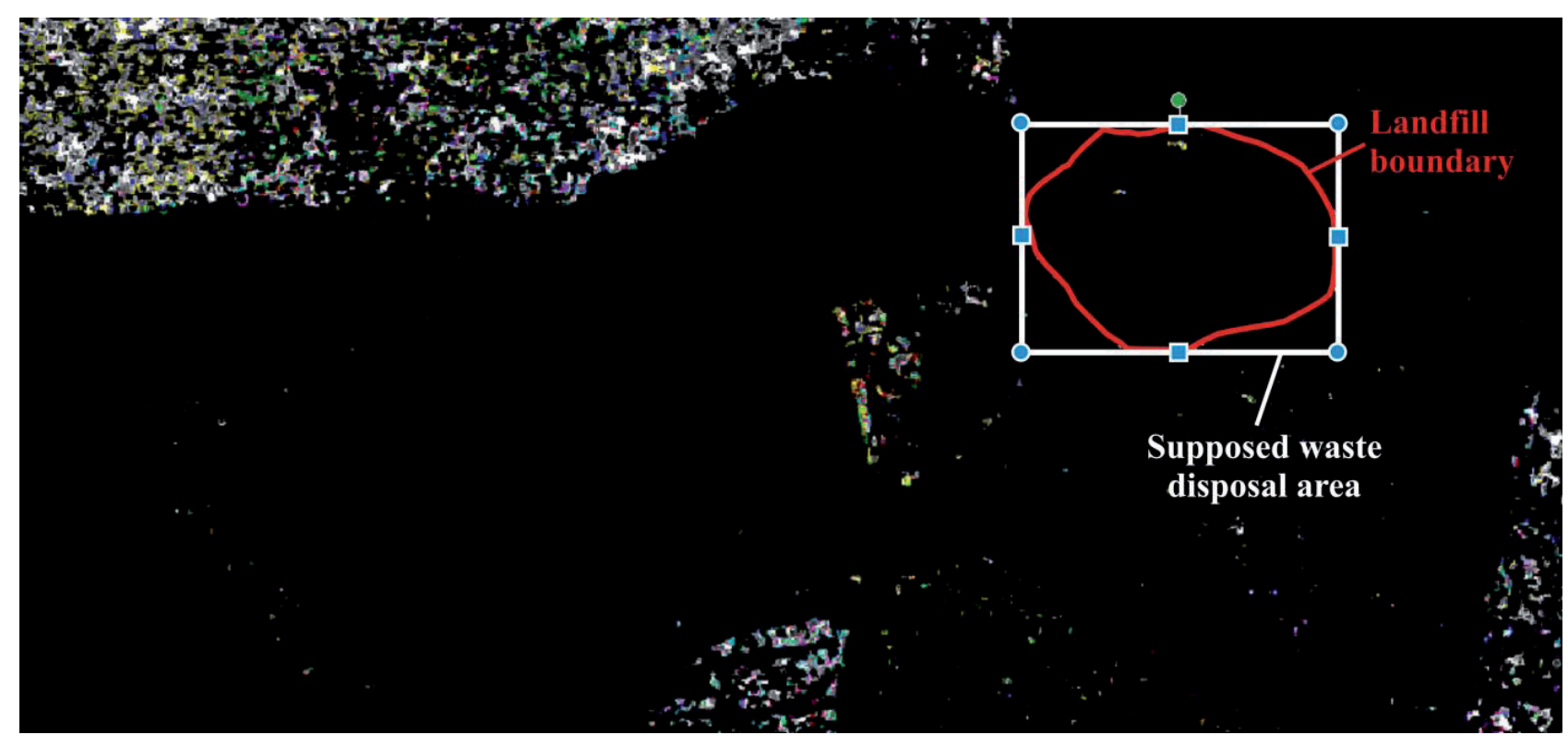

Figure 6. Excess built for Derhachi MSW landfill (October, 2017)

Table 1. Ranges of values of parameters of generalized model of the waste dump recognition using RSE (October, 2017)

\begin{tabular}{|l|c|}
\hline \multicolumn{1}{|c|}{ Parameter } & Range of values in accordance with histogram \\
\hline Mean value of pixel & $50-180$ \\
\hline Dispersion & $2-40$ \\
\hline Excess & $0-12$ \\
\hline Asymmetry & $0-5$ \\
\hline
\end{tabular}




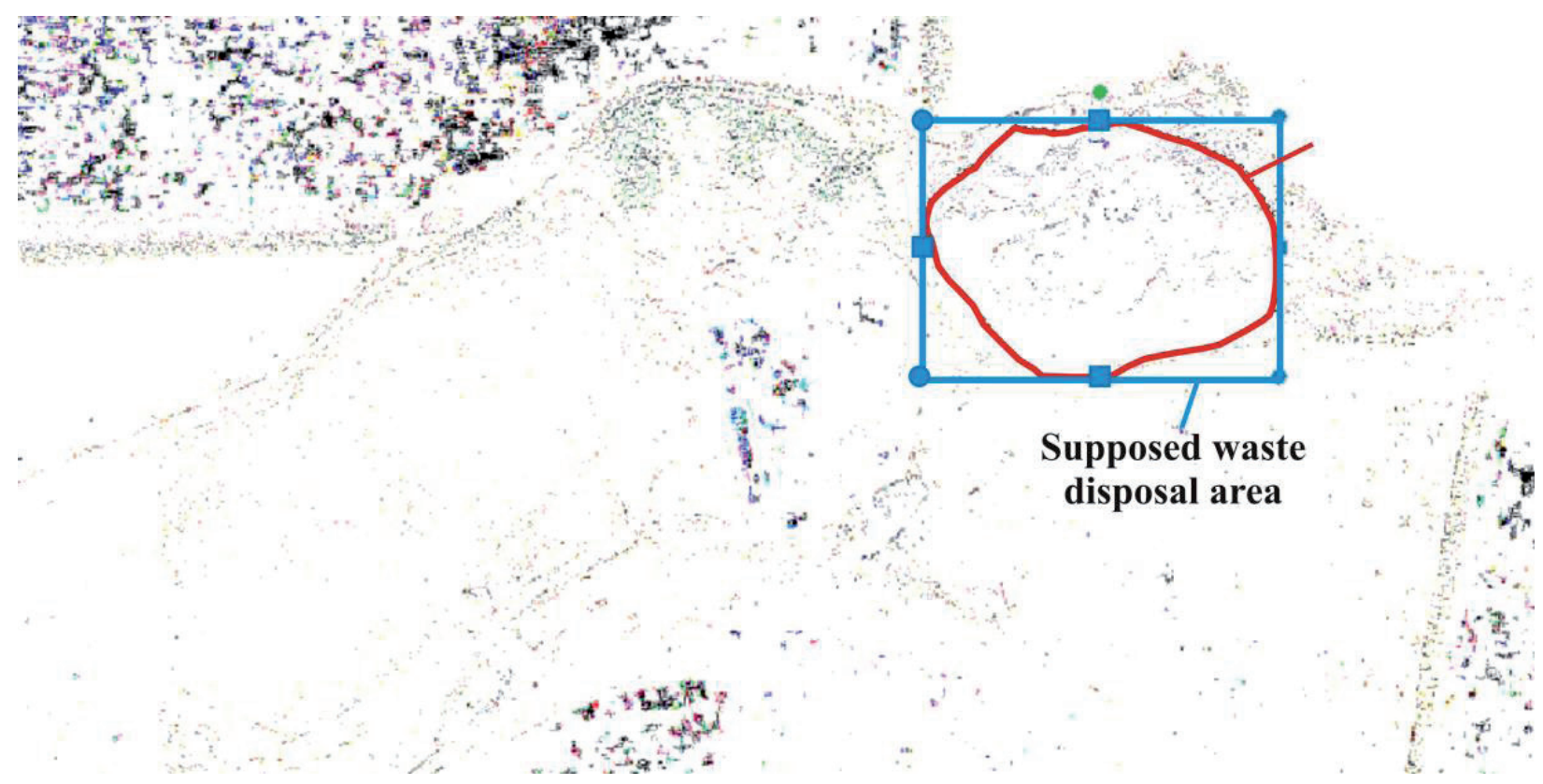

Figure 7. Asymmetry of Derhachi MSW landfill (October, 2017)
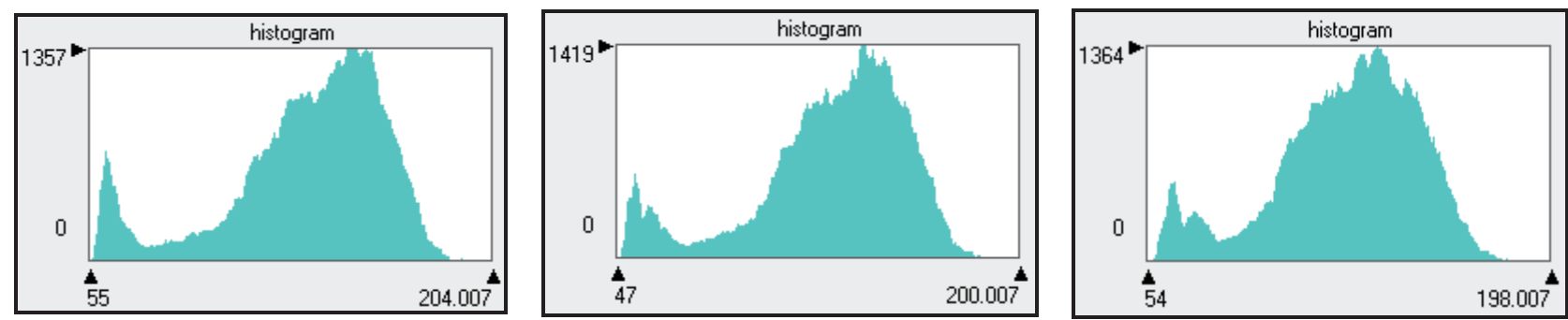

Figure 8. Histograms of pixel mean values built for Derhachi MSW landfill (October, 2017)
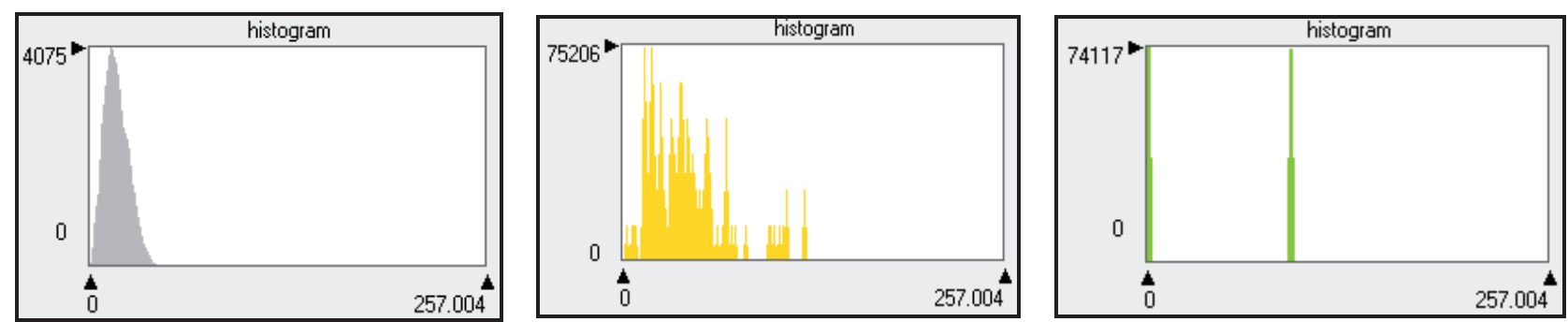

Figure 9. Histograms of dispersion, excess and asymmetry built for Derhachi MSW landfill (October, 2017) 


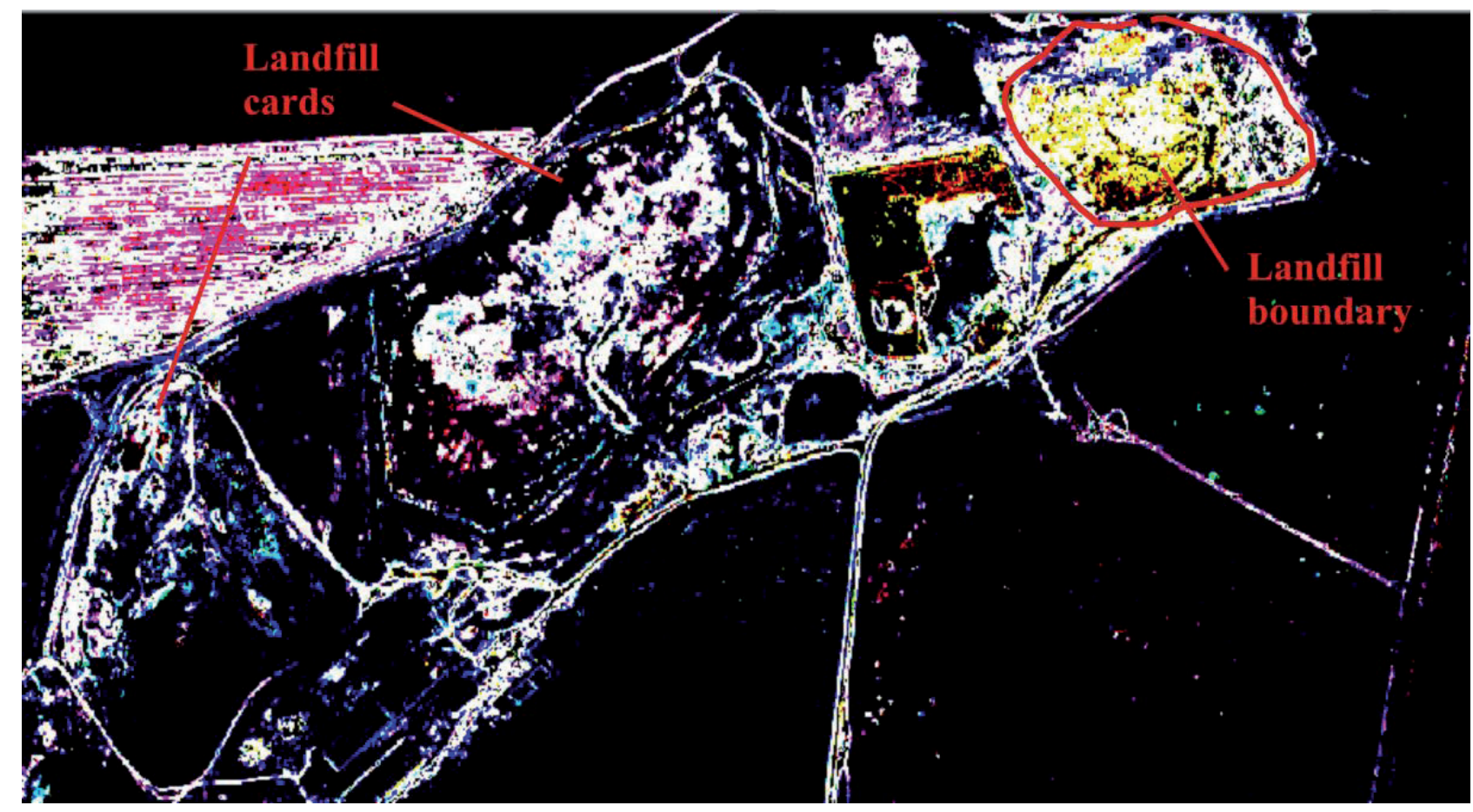

Figure 10. Borders of the waste dump recognized by means of RSE (October, 2017)

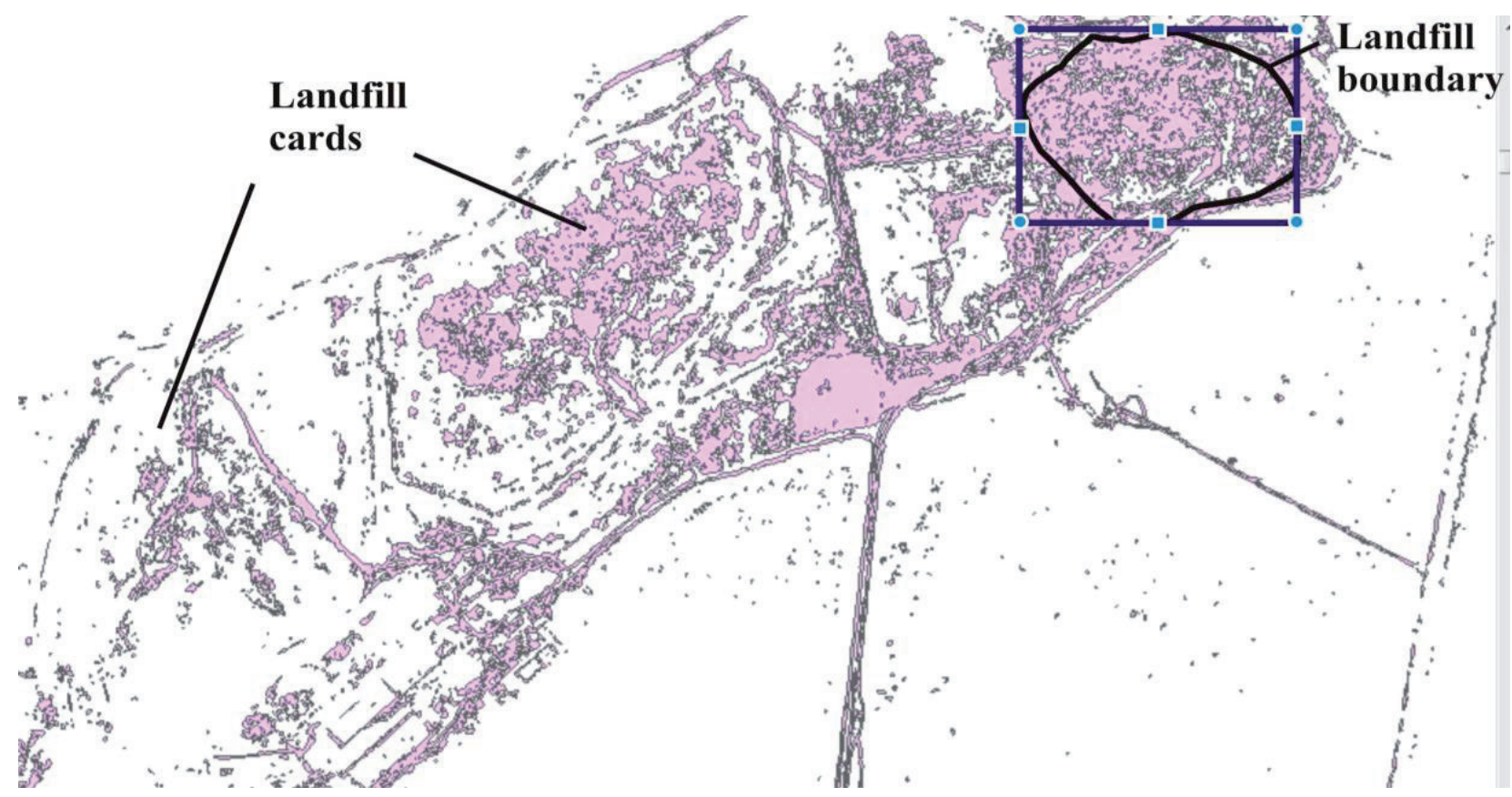

Figure 11. Vectorization of the recognized waste dump (October, 2017) 


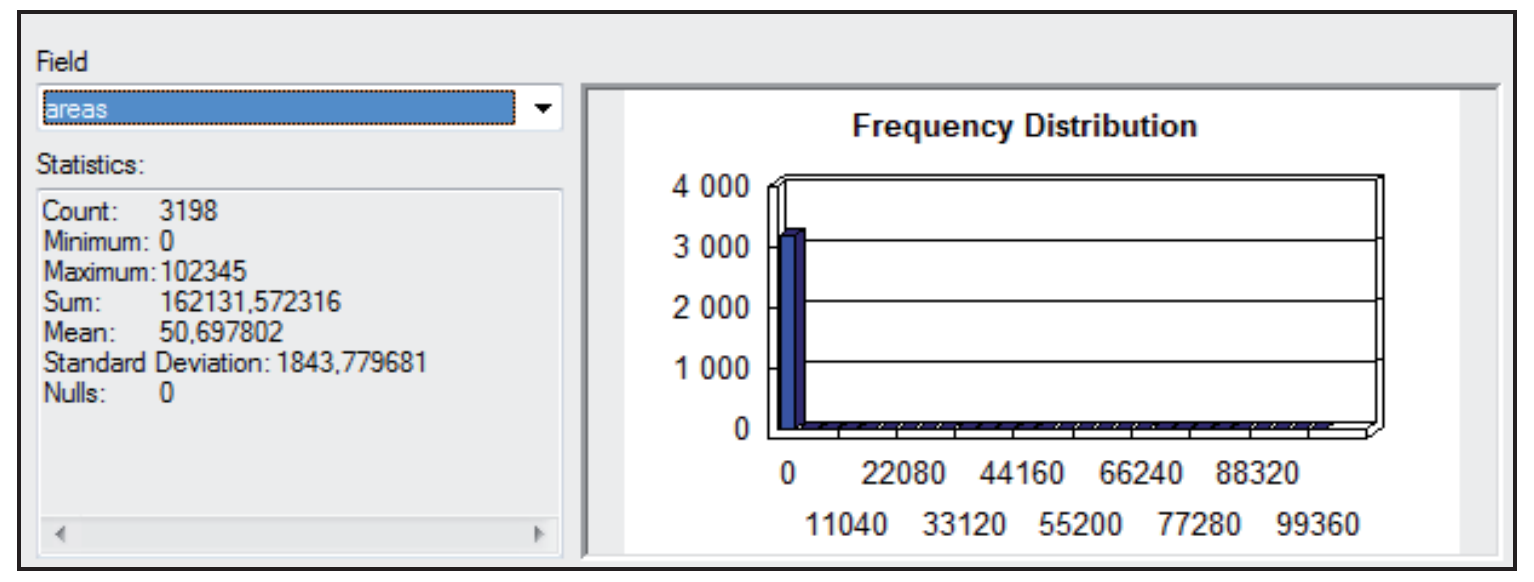

Figure 12. Surface area of the recognized waste dump (October, 2017)

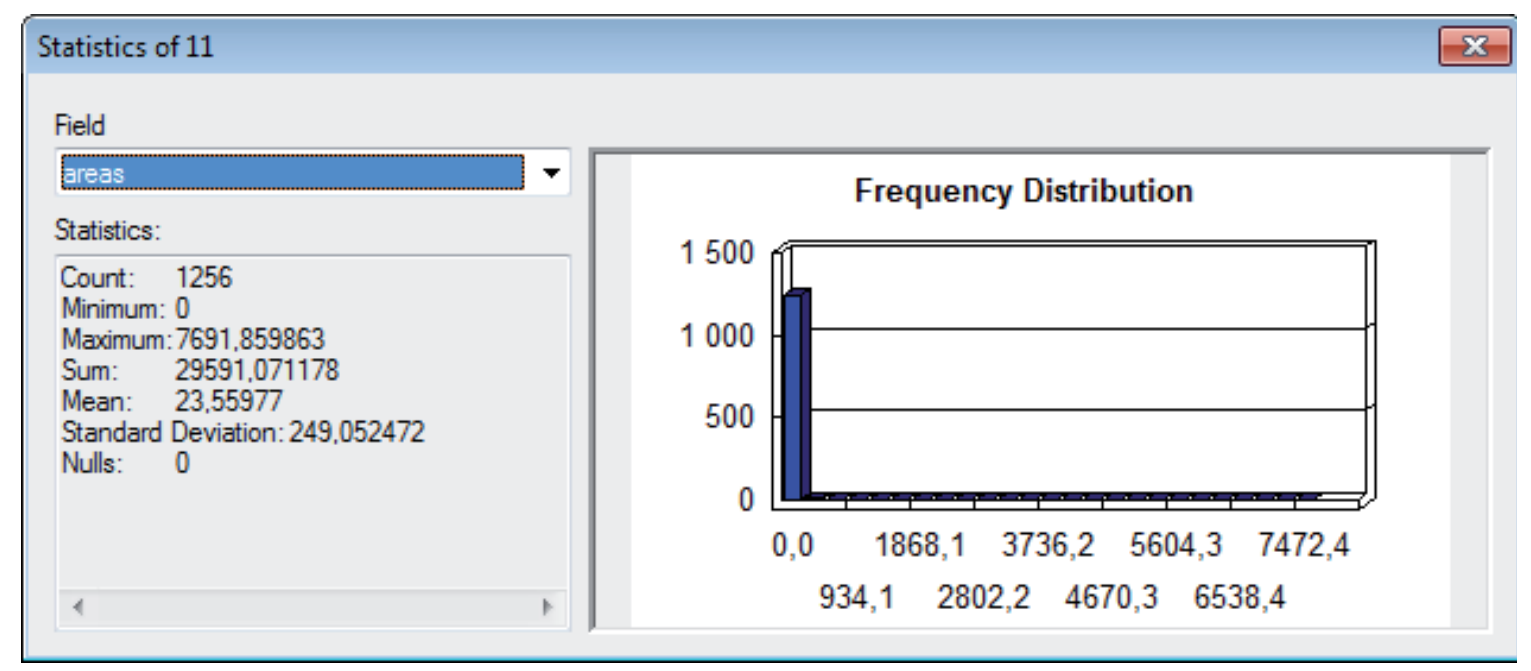

a

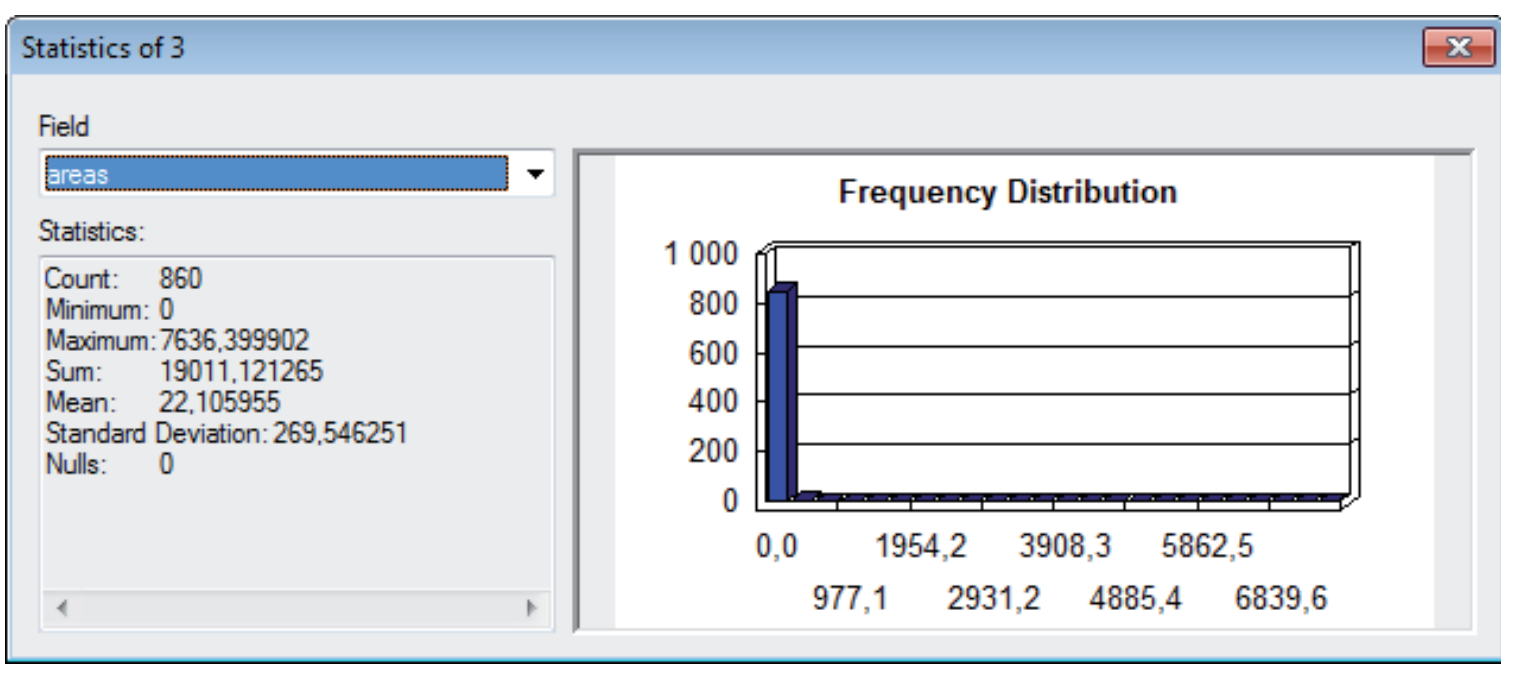




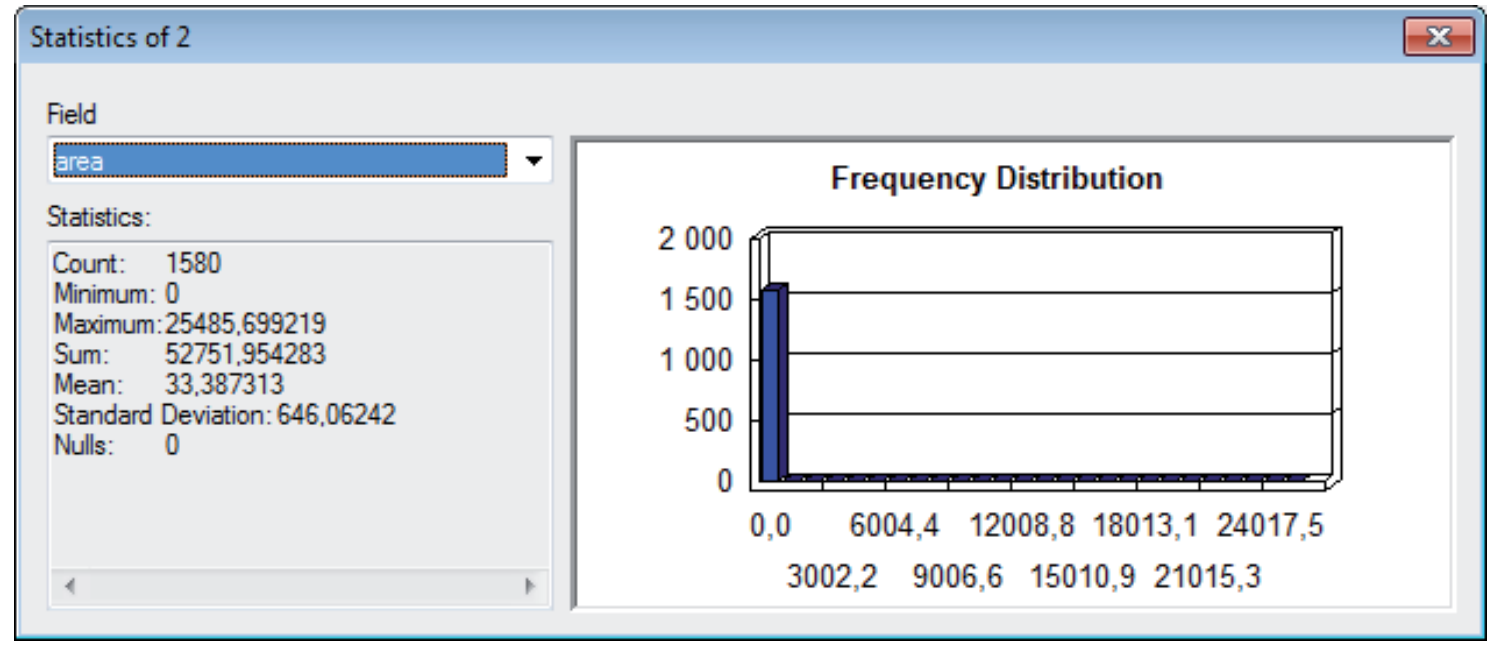

$\mathrm{c}$

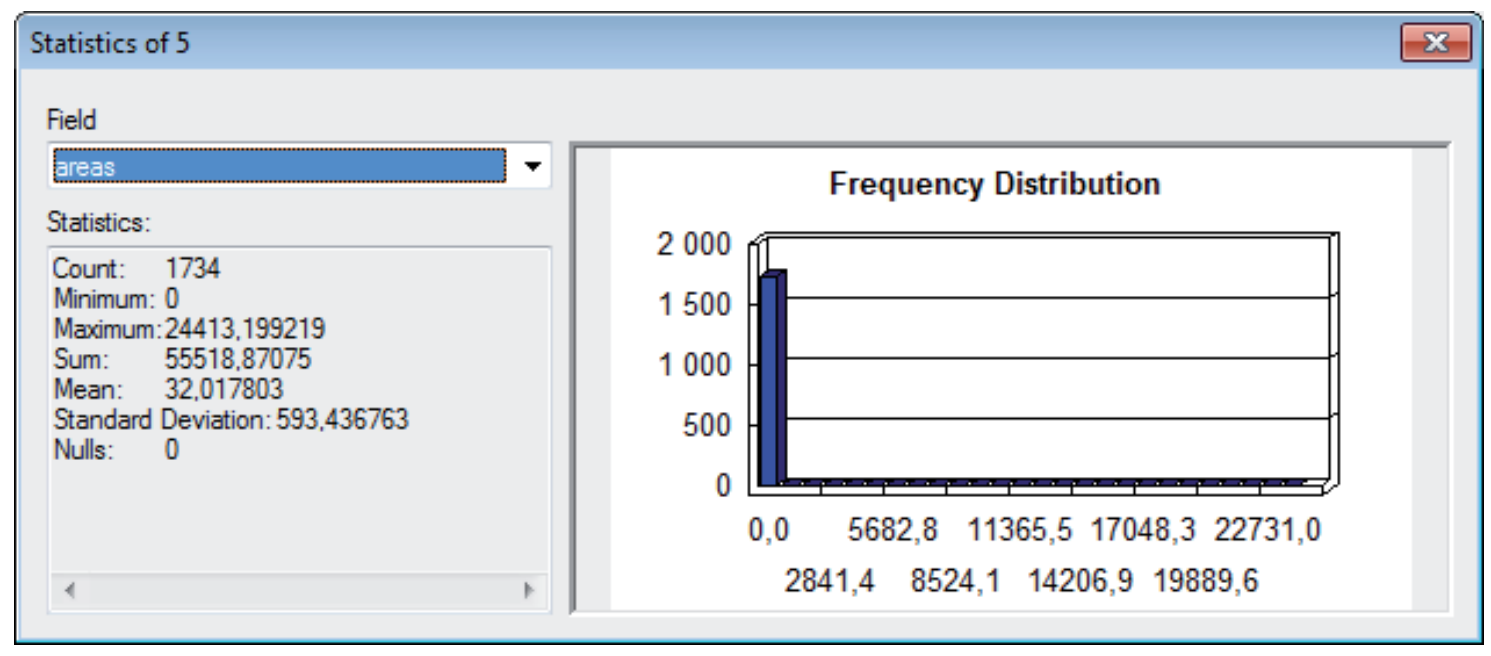

d

Figure 13. Surface area of the recognized waste dump (February - September, 2017).

a - February, 2017; b - May, 2017; c - August, 2017; d - September, 2017 
Surface area of the recognized waste dump with predominance of organic component, thousand $\mathrm{m}^{2}$

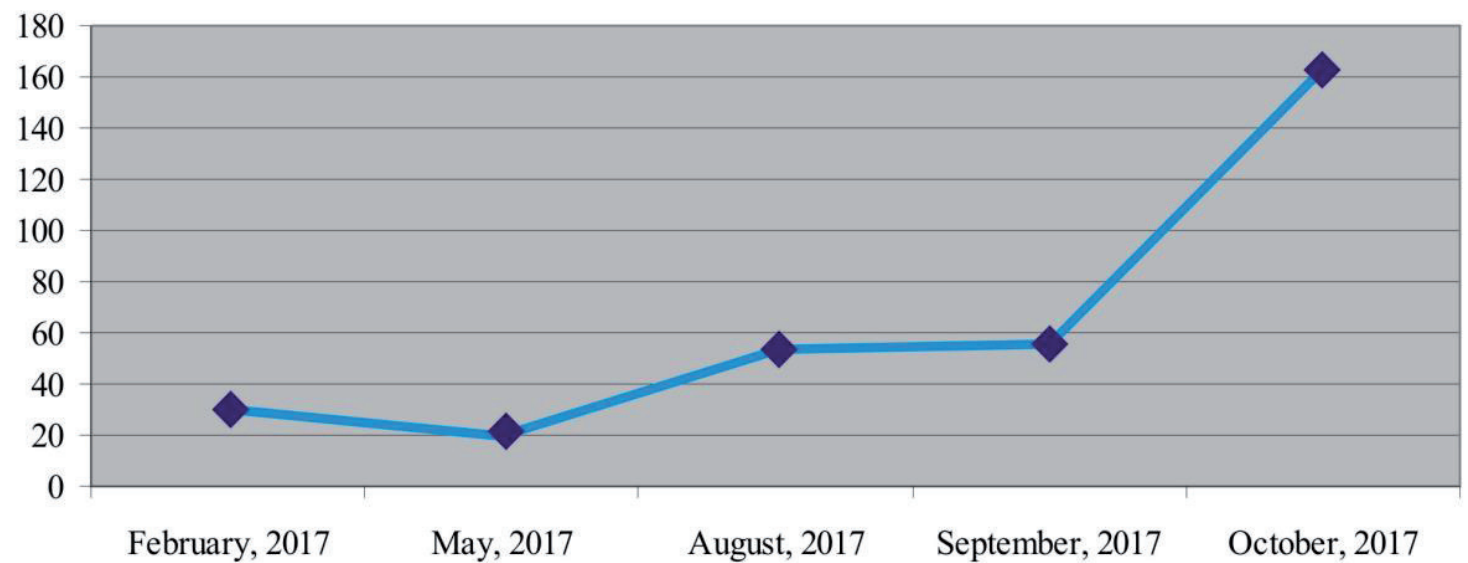

Figure 14. Dynamics of changes in the carbon-containing wastes area

ing to obtain fuel products suitable for storage (Vambol V., 2016; Vambol, S. et al., 2018b).

\section{Conclusions}

The following conclusions may be made on the basis of obtained results of the study:

1. Investigation and analysis of waste accumulation locations show heterogeneity of the waste materials and substances. In such case application of method of universal image classification for waste location revealing and surface area assessing does not provide necessary level of accuracy.

2. Developed specialized model is based on exclusion of the low hazard dump sites such as debris and rock masses. Its application allows to distinguish areas enriched with carbon-containing materials.

\section{Acknowledgements}

The authors are very thankful and acknowledge to Berdyansk State Pedagogical University and CSIRCIMFR, Dhanbad, India for respective organizations for granting permission to publish this work in the Journal.

\section{References}

Angelino C.V, Focareta M., Parrilli S., Cicala L., Piacquadio G., Meoli G. \& De Mizio M., 2018, A case study on the detection of illegal dumps with GIS and remote sensing images, [in:]. U. Michel, K. Schulz (eds), Earth Resources and Environmental Remote Sensing/ GIS Applications. SPIE Proceedings Vol. 10790. (doi: 10.1117/12.2325557).

Aristov M.A., 2009, Monitoring poligonov TBO i obnaruzhenie stihiinyh musorosvalok po dannym kosmicheskoi siemki. GeoProfil' 2: 34-41.

Chanakya H.N., Shwetmala K. \& Ramachandra T.V., 2015, Nature and extent of unauthorized waste dump sites in and around Bangalore city. Journal of Material Cycles and Waste Management 17(46): 1-9. (doi: 10.1007/s10163-015-0423-6).

Chinatsu Y., 2009, Possibility of Monitoring of Waste Disposal Site Using Satellite Imagery. JIFS 6: 23-28.

Corbyn L., 2008, Crackdown on illegal dumping. Handbook for local government, NSW. Department of Environment and Climate Change NSW, Sydney South 1232. (www.environment.nsw.gov.au).

Cui S.Y., Yan Q., Liu Z.J. \& Li M., 2008, Building detection and Recognition from High Resolution Remotely Sensed Imagery. Proceedings of XXI ISPRS Congress, Beijing 37: 411-416.

Domanska M.V.\& Bondar S.P., 2013, Identification of illegal dumps of domestic waste using materials of RSE. Cartography almanac 7: 114-126. 
Gorova A., Pavlychenko A., Kulyna S. \& Shkremetko O., 2015, Environmental aspects of waste management on coal mining enterprises, [in:] G. Pivnyak, V. Bondarenko, I. Kovalevska (eds) Theoretical and Practical Solutions of Mineral Resources Mining, Taylor \& Francis Group, London. (www.taylorfrancis.com/books/e/9781315648774/ chapters/10.1201\%2Fb19901-33).

Kalinin N.YU., 2013, Rozpiznavannya struktury kolorovykh fotohrammetrychnykh zobrazhen zemnoyi poverkhni za spektralnymy i strukturnymy oznakamy. Pratsi TDATU 4(53): 66-71.

Katharine G. \& Chang H.C., 2015, Review remote sensing analysis techniques and sensor requirements to support the mapping ofillegal domestic waste disposal sites in Queensland, Australia. Remote Sens. 7: 1305313069. (doi:10.3390/rs71013053).

Kohan S.S. \& Moskalenko A.A., 2009, Evaluation of possibility of identification of dumps using multyspectral space images. Herald of Geodesics and Cartography 6: 29-34.

Malovanyy M., Nikiforov V., Kharlamova O. \& Synelnikov O., 2016, Production of renewable energy resources via complex treatment of cyanobacteria biomass. Chemistry \& Chemical Technology 10(2): 251-254. (https:// doi.org/10.23939/chcht10.02.251).

Novokhatska N.A., 2015, Kompleksna otsinka ta prohnozuvannya vplyvu smittyezvalyshch na skladovi dovkillya: avtoref. dys kand. tekhn. nauk: 21.06.01 / Novokhats'ka Natalya Anatoliyivna. Kyiv. Nats. un-t budivnytstva i arkhitektury, Kyiv.

Oreshkina L.V., 2005, Obnaruzheniye i raspoznavaniye klassa ob»yektov na mnogozonal'nykh izobrazheniyakh distantsionnogo zondirovaniya. Informatika 2: 79-85.

Silvestri S. \& Omri M., 2008, A method for the remote sensing identification of uncontrolled landfills: formulation and validation. International Journal of Remote Sensing 29(4): 975-989.

Suchikova Y., Bogdanov I., Onishchenko S., Vambol S., Vambol V. \& Kondratenko O., 2017, Photoluminescence of Porous Indium Phosphide: Evolution of Spectra During Air Storage. Proceedings of the 2017 IEEE 7th International Conference on Nanomaterials: Applications and Properties (NAP-2017): 138-141.
Tompson L. \& Chainey S., 2011, Profiling illegal waste activity: using crime scripts as a data collection and analytical strategy. Eur J Crim Policy Res. 17: 179-201.

Trofimchuk O.M. \& Novokhatska N.A., 2014, Technology Inventory Solutions Vidalen Vidhozhv methods of remote sensing Earth Zemly. Ecological bezpeka and nature growers 14: 31-40.

Vambol S., Bogdanov I., Vambol V., Suchikova Y., Kondratenko O., Hurenko O. \& Onishchenko S., 2017a, Research into regularities of pore formation on the surface of semiconductors. Eastern-European Journal of Enterprise Technologies 3/5(87): 37-44. (doi: 10.15587/1729-4061.2017.104039).

Vambol S., Vambol V., Bogdanov I., Suchikova Y. \& Rashkevich N., 2017b, Research of the influence of decomposition of wastes of polymers with nano inclusions on the atmosphere. Eastern-European Journal of Enterprise Technologies 6/10(90): 57-64. (doi: 10.15587/17294061.2017.118213).

Vambol S., Vambol V., Kondratenko O., Koloskov V. \& Suchikova Y., 2018a, Substantiation of expedience of application of high-temperature utilization of used tires for liquefied methane production. Archives of Materials Science and Engineering 87(2): 77-84. (doi: 10.5604/01.3001.0012.2830).

Vambol S., Vambol V., Sobyna V., Koloskov V. \& Poberezhna L., 2018b, Investigation of the energy efficiency of waste utilization technology, with considering the use of low-temperature separation of the resulting gas mixtures. Energetika 64 (4): 186-195. (doi: 10.6001/ energetika.v64i4.3893).

Vambol V., 2016, Numerical integration of the process of cooling gas formed by thermal recycling of waste. Eastern European Journal of Enterprise Technologies 6/8(84): 48-53. (doi: 10.15587/1729-4061.2016.85455).

Vambol V.V., Shmandiy V.M. \& Kreta D.L., 2015, Monitoring of unauthorized places of waste accumulation using satellite imagery. Technology audit and production reserves 5/6(25): 42-45. (https://doi.org/10.15587/23128372.2015.51182).

Wood C. \& Lee N., 1995, Strategic Environmental Assessment. EIA Centre, University of Manchester. 